\title{
A imigração italiana no Inferno provisório
}

\section{The italian immigration in Inferno provisório}

Professor Doutor Assistente de Literatura Brasileira na Universidade Estadual Paulista (UNESP) - Ibilce Literatura Brasileira pela Universidade de São Paulo. (17) https://orcid org/0000-0001-8846-7913 E-mail: ulissesinfante@gmail.com
Ulisses Infante ${ }^{1}$ Faculdade de Letras e Ciências Exatas, Instituto de Biociências, Universidade Estadual Paulista São José do Rio Preto, SP, Brasil.

RESUMO: É principalmente nas narrativas de Mamma, son tanto felice, livro que desempenhou o papel de volume inicial da pentalogia Inferno provisório, que Luiz Ruffato representa as relações entre os imigrantes italianos e a realidade social e natural da Zona da Mata mineira a que se incorporaram durante a primeira metade do século XX - considerados aqui os limites cronológicos definidos pela obra. A partir de 2016, Inferno provisório assumiu a forma de volume único e Mamma, son tanto Felice deixou de existir como unidade independente: as narrativas que formavam o livro foram distribuídas pelo autor ao longo do novo volume. Por meio de técnicas narrativas que privilegiam a fragmentação, a focalização seletiva e a heterogeneidade discursiva, Ruffato encena aquilo que ele mesmo denominou "uma tragédia". O objetivo deste trabalho é expor os resultados da leitura e análise dos episódios de Inferno provisório cujo conjunto permite depreender uma interpretação do fenômeno histórico da imigração, não apenas a partir de pontos de vista subentendidos ou enunciados ao longo da narrativa, mas também decorrentes dos efeitos de sentido obtidos pela utilização de formas específicas de narrar na relação que estabelecem com a matéria narrada.

Palavras-chave: Luiz Ruffato; Romance brasileiro contemporâneo; Imigração italiana; Representação.

ABSTRACT: It is mainly in the narratives of Mamma, son tanto felice, once the first volume of the pentalogy Inferno provisório, that Luiz Ruffato focuses the relationship between the Italian immigrants and the social and natural reality of the Zona da Mata of Minas Gerais State to which they incorporated themselves during the first half of the twentieth century - considered here the chronological limits set by the book. From 2016 on, Inferno provisório became a single volume and Mamma son tanto felice ceased to be an independent unity: its narratives were distributed by the author alongside the new volume. Using narrative techniques that favor fragmentation, selective focus and discursive heterogeneity, Ruffato enacts what he called "a tragedy." The purpose of this paper is to disclose the results of the analysis of this novel in search of the interpretation of the historical phenomenon of immigration, not only considering the implied points-of-view or statements disposed throughout the narrative, but also taking into account those resulting from the effects of meaning obtained by the use of specific forms of narrating and the relationship they establish with the contents exposed.

Keywords: Luiz Ruffato: Brazilian contemporary novel: Italian immigration: Representation. 


\section{A partir de uma observação e de uma nota do autor}

$\mathrm{N}$

uma das últimas páginas de Mamma, son tanto felice, Luiz Ruffato apôs a seguinte observação:

Possível que alguma passagem de Mamma, son tanto felice, primeiro volume de Inferno provisório, seja reconhecida. Em verdade, reembaralhadas, aí estão uma das Histórias de remorsos e rancores (totalmente reescrita), três de (os sobreviventes) (revistas) e duas inéditas. L. R. (RUFFATO, 2005, p.173).

Com essa ressalva, o autor explicita aquilo que os leitores mais atentos de sua obra já vinham percebendo durante a leitura do livro: nele se faz o reaproveitamento de narrativas publicadas nos dois livros de contos que Ruffato publicara respectivamente em 1998 e no ano 2000, Histórias de remorsos e rancores e (os sobreviventes). Todas as histórias desses dois livros, aliás, foram incorporadas ao projeto Inferno provisório, cujos cinco volumes serão publicados ao longo de seis anos - Mamma, son tanto felice e $O$ mundo inimigo em 2005, Vista parcial da noite em 2006, O livro das impossibilidades em 2008 e Domingos sem Deus em 2011. No que diz respeito a Mamma, son tanto felice, importa destacar que as duas histórias inéditas são justamente as que abrem o volume, "Uma fábula" e "Sulfato de morfina" - o que também significa que, nesse desenho inicial do projeto narrativo, elas introduzem todo o conjunto da pentalogia. De Histórias de remorsos e rancores provém "O alemão e a puria", a quinta narrativa de Mamma. As três histórias de (os sobreviventes) incorporadas são: "Aquário", "A expiação" e "O segredo", respectivamente, a terceira, a quarta e a sexta (e última) narrativa de Mamma, son tanto felice.

A ressalva de Ruffato no final de seu livro aponta em várias direções. Há inicialmente a questão dos gêneros literários que levanta. Os volumes que compõem Inferno provisório são classificados como "romances" na lista de obras do autor já publicadas apresentada no final de cada um dos livros. Ao informar que neles foram incorporadas as histórias que antes figuravam em seus dois primeiros livros, Ruffato toca no problema da distinção entre formas narrativas e passa a fazer sentido indagar se Mamma, son tanto felice é um romance ou um conjunto de seis "histórias". O exame das formas e técnicas narrativas empregadas no livro indica que houve uma intencional opção por explicitar o quanto o conjunto é formado por unidades autônomas, unidades que, consideradas isoladamente, são completas em si mesmas; consideradas umas em relação às outras, atuam ao modo de capítulos, estabelecendo entre si nexos diversos - fato que se repete quando se toma cada um dos cinco livros em relação aos demais. Cada conjunto, cada "romance" do ciclo é, em si mesmo, mais do que a simples soma das partes que o formam, assim como ocorre com o ciclo em relação aos romances que o integram: há, além das narrativas, todo o conjunto de laços e referências recíprocas que estabelecem entre si.

Esse modo de construção parece querer evidenciar que o recorte do universo representado nas narrativas está sempre vinculado às formas de mediação que o texto estabelece com o leitor: pode-se até experimentar a sensação de se estar lidando com uma totalidade, mas é sempre possível no jogo narrativo relativizar essa totalidade ao enquadrá-la em outra que lhe é superior em termos de abrangência e assim sucessivamente. Ao menos numa primeira interpretação, esse procedimento tende a desautomatizar as formulações de juízo por parte do leitor, já que o leva a reconsiderar sua avaliação sempre que tem de lidar com vínculos entre as várias históriascapítulos e os vários romances-volumes.

Além disso, a observação de Ruffato propõe um despistamento quando afirma que as histórias reaproveitadas foram "reembaralhadas". A análise da organização de Mamma, son tanto felice sugere que não há no livro 
um embaralhamento no sentido de desorganização que o termo costuma ter. Há, pelo contrário, uma ordenação que permite identificar um fio cronológico insinuando-se por sob as partes do romance, particularmente se se consideram os fatos relacionados à imigração italiana na Zona da Mata mineira e seus desdobramentos. Esse fio cronológico estende-se ao conjunto da pentalogia, cujas ações vêm-se desdobrando do passado para a contemporaneidade. Pode-se cogitar que o embaralhamento seria então de outra ordem, já que as vidas representadas de fato se interpenetram muitas vezes em função de fatores que podem parecer aleatórios num exame superficial.

Importa destacar que as duas histórias inéditas foram estrategicamente escritas para permitir o reaproveitamento do material anteriormente publicado em parte do ciclo Inferno provisório. Como se desenvolverá adiante neste trabalho, com "Uma fábula" Ruffato propõe uma cosmogonia para o universo ficcional cujo amplo painel começa a desdobrar nesse primeiro volume de Inferno provisório; "Sulfato de morfina" apresenta dados sobre a imigração italiana que a retiram da atmosfera mítica da primeira narrativa e a historicizam. Nesse capítulo e nos seguintes, os imigrantes italianos e seus descendentes passam a subordinar-se às mesmas regras de causalidade que os habitantes da Zona da Mata de ascendência diferente enfrentam, com os quais, aliás, vêm a estabelecer laços de diferentes tipos, integrando-se todos numa mesma categoria social a que se poderia chamar de proletariado urbano de origem rural.

Em 2016, Inferno provisório foi publicado em formato de volume único. $\mathrm{O}$ autor operou diversas transformações no conjunto de romances: os títulos Mamma, son tanto felice e $O$ livro das impossibilidades são abandonados, enquanto os títulos dos outros livros são transformados em títulos de seções da obra reestruturada. Logo após o índice do volume, Luiz Ruffato dispôs a seguinte nota:
Em 1998, com o lançamento de Histórias de remorsos e rancores, seguido de (os sobreviventes), em 2000, começou a tomar forma o catálogo de histórias Inferno provisório, que ao longo da primeira década do século XXI materializou-se em cinco volumes: Mamma, son tanto felice, $O$ mundo inimigo, Vista parcial da noite, O livro das impossibilidades e Domingos sem Deus. Agora, revista, reescrita e reestruturada, torna-se esta a edição definitiva, que dedico a Helena Terra (RUFFATO, 2016, p.13).

"Uma fábula" foi mantida como a narrativa inaugural do conjunto, a que o autor denominou "catálogo de histórias", enfatizando o caráter de unidades autônomas mas interligadas das histórias-capítulos. A reestruturação foi profunda, embaralhando (para usar um termo do próprio autor) as histórias dos vários volumes, o que modificou a cronologia dos acontecimentos, que agora não mais avançam em sequência temporal, mas constroem um tecido narrativo repleto de avanços e recuos temporais. Essas idas e vindas explicitam as relações de causalidade internas ao processo histórico representado, como se irá destacar mais adiante neste trabalho. Apesar de a nota acima citada propor que se trata da "edição definitiva" de Inferno provisório, a própria arqueologia da obra que é aí apresentada parece ressaltar que se trata de projeto em andamento.

\section{2 “Uma fábula"}

A primeira história-capítulo de Mamma, son tanto felice e da edição de Inferno provisório de 2016 (na qual adquire o status de uma seção da obra) se abre apresentando André, um dos dois filhos homens do casal Micheletto que vingaram. Essa abertura é importante para a estratégia narrativa adotada, pois em vários momentos se vai apresentar o mundo narrado a partir da focalização de André. O personagem que domina a história é o Micheletto velho, mostrado em sua ação de herói civilizador sobre o espaço ainda selvagem, o que o elevaria à condição de patriarca fundador de uma estirpe: 
Desdobrou a família, entre machados e queimadas, arados e enxadas, no fundo do fundo de uma barroca enquistada meio caminho de Rodeiro para a Serra da Onça, por detrás, cruzando enviesado pelas Três Vendas, pouco mais ou menos coleando as águas nervosas do Rio Xopotó, uma grota adquirida com o sol montadonas costas, nos encabritados cafezais do Piau, solto no mundo, desmamado de pai e mãe, enfezado na empreita da limpa das ruas até a panha dos grãos maduros, para depois, orgulhoso, nota sobre nota, escriturar aquele mataréu vassalo de bestas selvagens, uma imundície de jaguatiricas e jaracuçus gordas como braço de homem-teba, veados mateiros e cachorros-do-mato, sapos-cururu e tatus-galinhas, macacos-prego e lobos-guará. Estreou derribando árvores e alastrando fogo nos tocos, puxando água de uma mina com engenharias de bambus-gigantes, marretando pedras para soldar as bases do corpo da casa seis-cômodos, as mãos febris de calos, os ombros empapados de sangue pisado. Aprumou paredes na amarração de caibros e cumeeiras, recobriu o teto, tijolos e telhascumbuca trazidos em lombo de burro da olaria do Antônio Spinelli para industriar aqueles fins de tudo. E, presidiário de sua obsessão, comeu sete meses de sua vida na ampla solidão do paraíso, labutando de antes do sol espantar a roncaria da madrugada até os dedos formigarem de sono, pois urgia o tempo: à luz de lamparinas caprichava na carpina - mesas, banquetas, baús, bancos, guarda-roupas, guarda-comidas. Quando deu por finda a faina convulsiva, compareceu, fosse uma visão, na Rua, socado dentro de um terno-gravata marinho mandado feitiar no Singulani, asas imensas na senjeiteza dos modos, pés escalavrados no pelourinho da bota rinchando de nova, de casa em casa da colônia caçando a eva que iria povoar aquele mundo virgem de vozes. Demorou um nada para preferir uma menina-Bettio, Chiara, recém-moça, catorze anos, que, pela largura das ancas mostrava-se boa parideira, embora magra e intimidada, corpo forrado de sardas, e fraca da cabeça, como descobriria depois, já fora de prazo para desfazer o negócio (RUFFATO, 2016, p. 17-18).

Num parágrafo, sumariza-se a atuação do Micheletto velho em sua "faina convulsiva": "solto no mundo", desligado das próprias origens, trabalhador nos cafezais do Piau, logo proprietário de um mataréu no meio do caminho entre Rodeiro e a Serra do Onça, desbastado a machado e fogo e a seguir transformado em sede de uma casa erguida e mobiliada por esse "presidiário de sua obsessão".

Importa destacar que o excerto apresentado ilustra muito bem a linguagem cunhada por Ruffato para sua fábula: é uma língua híbrida, em que termos de origem indígena, formas populares, vocabulário nobre, nomes próprios italianos se mesclam num idioma literário mestiço, forjado para representar um processo de transposição e hibridação cultural. O Micheletto velho, verdadeiro Adão num mundo primevo, logo decide que deve povoar seu "paraíso" e, apresentado desde então como alguém um tanto imaterial ("fosse uma visão" diz o texto), caça a "eva" com quem iria levar a fala humana àquele "mundo virgem" que, com seu trabalho, lograra ordenar no "fundo do fundo de uma barroca". São detalhes habilmente dispostos que fazem de "Uma fábula" um texto fundador também na recuperação de elementos típicos de textos míticos que opera. No trecho citado é evidente a intertextualidade com o Gênesis bíblico, o que acentua ainda mais o caráter de narrativa das origens que "Uma fábula" desempenha no romance e no ciclo inteiro. Um dos efeitos é mergulhar na imprecisão a delimitação cronológica dos acontecimentos: historicamente, a imigração italiana para a Zona da Mata mineira se deu com maior intensidade no final do século XIX, arrefecendo na primeira década do século XX - mas a atuação do Micheletto velho ocorre em momento posterior, na primeira metade do século $\mathrm{XX}$, como se poderá constatar a partir de informações fornecidas em "Sulfato de morfina". Esses limites históricos, a esta altura, pouco importam, pois trata-se de personagem cuja construção está intencionalmente impregnada de índices do mundo da memória oral, como a indicar uma pré-história cujo acesso pela mentalidade histórica não se faz com facilidade, já que o desencantamento do mundo ainda não se verificara naqueles momentos míticos.

Além da ressignificação de elementos do Gênesis, outras conexões intertextuais logo se fazem perceber: o tratamento que o Micheletto velho 
dedica à infeliz eva eleita, Chiara Bettio ${ }^{1}$, desde sempre afastada da família e aprisionada num quarto da casa com a função exclusiva de parir filhos, traz à lembrança a fábula do Barba Azul, parodiada por meio de um processo de inversão de expectativas, pois, neste caso, os irmãos da esposa nada conseguem e ela só pela morte se liberta do estado opressivo em que vegeta. A recuperação dessa fábula é particularmente importante, pois muito do futuro fracasso do Micheletto velho parece provir dessa sua dissociação da vida coletiva, que impõe aos seus um isolamento até mesmo em relação à própria família. No trecho seguinte, delega-se o olhar a André, que assim se recorda da figura paterna:

Mais tarde, André recordaria as madrugadas em que, desperto pelo zunzum da noite, espiava, pela greta da janela do quarto que dava para a vargem, o Pai de pé, envolvido pela friagem, esticando a vista treva adentro para consultar cada planta, cada animal, cada broto, cada filhote; macho o suficiente para abandonar a soca e guerrear com uma onça que rasgou o Nego, bostinha de cadeloespojador, bobo, interesseiro, covarde, mas registrado entre seus haveres; enérgico o tanto que capaz de enfieirar os anos sem se dirigir à pessoa de sua esposa, desdenhando-a até na missa de corpo presente, por entendê-la inapetente para gerar filhos-homens, ou, parindo-os, para administrá-los vivos, pois, dos cinco meninos, só dois sobrevieram no tempo. Os restantes foram-se, caídos um a um pelos sete palmos, o de três ofendido por urutu-cruzeiro; o de doze, estrepe no pé, que nem emplastro de língua-de-vaca com azeite-doce sujigou, morreu preto, feito o lombo luzidio de um negro no eito; o de dezoito, macambúzio, com as vísceras corroídas pela formicida (RUFFATO, 2016, p. 18-19).

O Micheletto velho era de tal forma obsedado pelo sentimento de posse, que chegou a enfrentar uma onça por ela lhe ter matado um cão, não porque se tratasse de um animal de valor, mas apenas e tão somente porque lhe

O sobrenome Bettio surge na edição de 2016 de Inferno provisório em substituição à forma Bicio, que era usada em Mamma son tanto felice. pertencia. O dia ainda não nascera, e ele já lançava seu olhar proprietário sobre cada item de seu patrimônio, que, descobre-se durante a leitura da narrativa, incluía também os membros de sua família, sobre os quais tinha o direito de administrar sua própria justiça, como a que dedicava à esposa, trancafiada em casa porque "fraca da cabeça" e incapaz de gerar ou fazer vingar os filhos homens, ou a que realizara no duríssimo episódio da filha mais velha, que, capturada após a fuga com um caixeiro-viajante, fora sentenciada à morte e executada pelo próprio pai. A relação que o Micheletto velho sabe estabelecer com tudo e todos é de posse e instrumentalização: assenhorear-se de terra, bichos e gente parece ser um fim em si mesmo para esse adão das brenhas, cuja obra civilizatória não conduz ao bem-estar coletivo. Esse misto de paraíso natural domesticado à força e território feudal para o livre exercício do arbítrio pessoal que o Micheletto velho construiu tem uma história que se dobra sobre si mesma: senhor absoluto desse espaço conquistado e formado por sua ação demiúrgica, o patriarca carrega em si também uma semente de fracasso e inoperância, e o mesmo agente da transformação do espaço natural em espaço humano cultivado é o fomentador do processo inverso, em que a natureza recupera o que um dia lhe pertencera:

Depois que enterraram a Louca, o Pai, besteiro, concordando na diáspora dos sobrantes, dispersos aos quatro cantos, sitiou-se na fazendola homiziado entre os animais, comendo, bebendo e dormindo com eles, bicho ele mesmo, cevando conversas acaloradas em tardes agônicas, cadeiras espalhadas pelas calçadas de Rodeiro, pito de mães para exemplar criança espevitada, depois alusão, lenda, nada, enfim: a barroca asselvajada, temida, submersa no silêncio primevo, encapsulada no esquecimento, suspensa na memória (RUFFATO, 2016, p. 21)

Note-se nesse trecho o surgimento da palavra "diáspora", signo fundador no painel de transformações sociais que Inferno provisório representa, 
já que os personagens seguem com frequência um esquema que prevê sua partida do lugar de origem e sua fixação incômoda num ponto de chegada no qual ao tormento da precariedade econômica se costuma agregar a infelicidade pela ausência de referenciais identitários. Filhos de sucessivas diásporas povoam as páginas do Inferno provisório, a começar pela dos italianos chegados à Zona da Mata mineira, passando pela dos colonos de Rodeiro transformados em operários mal pagos em Cataguases e ainda outras, até a dos cataguasenses convertidos em metalúrgicos na Grande São Paulo. Ou, nas palavras do próprio Luiz Ruffato: “Todos os meus livros, de uma forma ou de outra, tratam de uma única questão: o desenraizamento." (RUFFATO, 2014). E esse primeiro dispersar de personagens autorizado pela decaída figura paterna, nesta primeira narrativa desse processo ininterrupto de desenraizamento que é a pentalogia reestruturada em volume único, sugere possibilidades interpretativas fecundas: é a seu modo uma reedição da queda do mito adâmico, uma reencenação da perda do paraíso terreal em dimensão paródica, já que, desta feita, o inexorável criador de si mesmo e do seu mundo submerge numa indiferença crescente pela sua obra, dissolvendo-se num apagamento que o neutraliza gradualmente em bicho, em argumento de pito materno, em alusão e lenda, em nada. Potencialmente, no entanto, parece preservar alguma possibilidade de manifestação, pois permanece como cápsula suspensa na memória.

"Uma fábula" representa também um processo que reedita a conquista do Novo Mundo pelo europeu: o espaço é dominado com energia e violência, a natureza é subjugada por figuras patriarcais que têm até mesmo o direito de privatizar a aplicação da justiça. É um processo brutal, uma fundação que é ao mesmo tempo uma queda, já que se constitui com base em interesses individuais e iniciativas privatistas indiferentes a toda forma de respeito ao ambiente e à dignidade humana - e o resultado é a instauração de desequilíbrios fundamentais que aderem às gerações subsequentes como mácula indelével de um erro original insuperável cometido num espaço e tempo edênicos. Isso se deu na conquista do século XVI e, na representação proposta por Luiz Ruffato, repetiu-se com a chegada dos imigrantes italianos, que, de acordo com "Uma fábula" - e também com outras histórias de Inferno provisório - como se verá adiante, reaplicaram procedimentos dos primeiros tempos da conquista da América.

A cena final de "Uma fábula" apresenta André aos catorze anos de idade num leilão de igreja a ponderar sobre a vida que leva. Fica a sugestão de que o que fora narrado até então era um longo repassar do personagem por suas origens, nas quais o Micheletto velho avulta com todo o peso de uma figura paterna autoritária e castradora, o "macho mais velho" (FREUD, 2013, p. 193) da horda primitiva que Freud encontrou em Darwin e analisou em "Totem e tabu". No presente da narrativa, André aluga sua força de trabalho nas propriedades vizinhas, já é proprietário de uma bicicleta Göricke ornada de acessórios, já passa Brylcreem nos cabelos (está, evidentemente, integrado a um mundo de consumo de que o Pai não participou) e espia as prostitutas em Rodeiro, sonhando com o dia em que terá coragem de chegar a Ubá e Cataguases, os maiores centros urbanos da sub-região. Subitamente, surge o irmão Pedro, acompanhado de um homem, "espessa barba preta" (RUFFATO, 2016, 22), a quem André é apresentado - e logo os dois irmãos são convocados por esse homem, cujo nome é Salvador e que afirma categoricamente: "Vou precisar muito de vocês" (RUFFATO, 2016, p. 22). Novamente, em chave irônica, "Uma fábula" tangencia os mitos, já que põe em cena um Salvador que precisa muito de Pedro e André - são claros aqui os laços com o Novo Testamento ${ }^{2}$

${ }^{2}$ Essa aproximação entre "Uma fábula" e o texto bíblico foi enfatizadapor uma modificação que o autor introduziu na vers̃a de 2016. Na edição de Mamma, son tanto felice, o narrador informa que o Micheletto velh recorria aos nomes de parentes para decidir como fictizaria os filhos (RUFFAT0 que

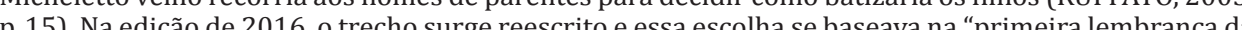
Bíblia" (RUFFATO, 20016, p.17) 
bíblico, particularmente a passagem em que os irmãos André e Pedro são chamados a deixar de lado os peixes para se tornarem pescadores de homens. A que se destina a convocação dos filhos do Micheletto velho o texto não informa, e essa reedição paródicados primeiros passos na constituição do apostolado de Jesus Cristo se institui como mais um elo da dissolução dos vínculos dos filhos do Micheletto velho e Chiara Bettio com suas raízes. Deste ponto de vista, os mitos, diferentemente do que Fernando Pessoa afirma (PESSOA, 1993, p.17), são o nada que, ainda que momentaneamente criem algo, destinam-se a reafirmar que ao final só se pode tornar ao nada.

"Uma fábula", como visto até aqui, desempenha o papel de instância de abertura do Inferno provisório, estabelecendo um vínculo entre o universo que se vai representar e uma origem que se perde na atemporalidade mítica - ainda que o tempo cíclico do mito seja aqui formulado na recondução do nada ao nada. Há pelo menos dois momentos posteriores no conjunto narrativo em que as referências a este texto inaugural são explícitas. 0 quarto volume da pentalogia, O livro das impossibilidades, abre-se com "Era uma vez"; na reestruturação em volume único, essa história passou a integrar a quarta seção do livro, "Um céu de adobe”. Já o quinto e último volume, Domingos sem Deus, encerra-se com "Outra fábula", que, na edição de 2016, transformou-se na narrativa final de todo o conjunto e foi elevada à categoria de seção. Em ambos os textos, o personagem Luís Augusto relembra sua trajetória profissional, de vendedor de salgadinhos em Cataguases a jornalista em São Paulo. "Era uma vez" concentra-se em relatar a primeira viagem de Luís Augusto a São Paulo, quando, ainda adolescente, conheceu a cidade em companhia do pai. "Outra fábula" narra a ida definitiva para a cidade grande, as dificuldades com o trabalho, o casamento, a chegada dos filhos. E fixa, principalmente, o projeto de vida de Luís Augusto:
E determinou-se a contrariar o destino: se operária sua involuntária ascendência, outra seria sua posteridade; se arribavam os colegas para atar casamentos apalavrados com desesperançadas penélopes, acercaria apenas de mulheres de distantes lugares; se natural fortalecer laços antigos por meio de inquebrantáveis amizades e parentescos inevitáveis, desprezaria datas festivas, sodalícios, comemorações, solenidades, reencontros, saudades (RUFFATO, 2016, p. 394).

Concebendo-se, a exemplo do Micheletto velho, como fundador de uma nova estirpe, Luís Augusto pretende fazê-lo a partir do rompimento com a própria origem. Na dimensão ultraurbana em que se inseriu, anônimo no mundo do capitalismo tardio e periférico brasileiro, reencena outra fábula, o que, no conjunto das relações de sentido que Ruffato estabelece, indica outro percurso rumo ao desenraizamento, à inadequação, ao humano desumanizado, o que é sem dúvida uma das formas do nada. Seria esse o eclodir daquela cápsula de memória em que se convertera o Micheletto velho?

\section{3 "Sulfato de morfina"}

"Sulfato de morfina" é a segunda história-capítulo de Mamma, son tanto felice, e, juntamente com "Uma fábula", era inédita quando da publicação do livro. Na edição em volume único de 2016, essa história passou a fazer parte da penúltima seção do livro, "Domingos sem Deus". Narra-se aqui a agonia de Dona Paula Bettio, irmã da Micheletta velha, a Chiara Bettio de "Uma fábula". É nesta história que se informa que Chiara esteve casada com o Micheletto velho durante vinte e um anos, o que permite inserir "Uma fábula" no processo histórico, já que o próprio autor situa os acontecimentos de Mamma, son tanto felice na década de 1950 (RUFFATO, 2008). Envelhecida e doente, D. Paula é, no presente narrativo, vizinha de uma de suas filhas, Regina. É essa filha que acode quando a mãe, lavadeira, sofre um ataque 
em meio ao trabalho. Acamada, provavelmente sedada devido à dor que o câncer lhe provoca, D. Paula como que libera o passado a fluir na memória:

Família... casamento... filhos... uma insidiante epiderme de mofo impregna tudo, esporos furtivos carcomendo qualquer esperança... Toda história é remorso... Assim, nos primórdios, assim, sempre... Uma praga, uma maldição desembarcada do navio Adria, no Rio de Janeiro, camuflada na bagunça das tralhas recolhidas aos baús dos Bettio, dos Furlaneto, cujo sangue, cinco anos mais, se misturaria, a ansiosa melancolia de Giacinto, a nostalgia embirrada de Ema, ele, vinte e dois, ela, quinze anos. Corcoveando o mar oceano pulgas, baratas, percevejos, ratos, hirtos pescoços proprietários do impossível retorno, ignorantes do daqui a pouco, no nunca jamais enterrados os ossos antepassados, soterrados os corpos, rasgadas as memórias do visto, saboreado, cheirado, pegado, ouvido, o Brenta, o paesello, as Dolomitas, a Basílica do Santo, martirizada a vida em estrangeiras manhãs suarentas, sob a planta dos pés terras ordinárias, casebres escalando montanhas em perdidos sertões, saúvas, redescobrimentos. E exsurge, imenso, o

(Põe a coberta devagar... senão ela acaba acordando... Isso...)

Inferno, não o do catecismo, labaredas fustigando condenados, tridentes quebrantando pecadores, gritos de tardios arrependimentos, mas outro, encenado em certa casa, oculta trás um basto bambuzal, para onde convergiam caminhos de formiga, minúscula se avistada do topo do pasto, arrogante se de sob o assoalho carunchado (RUFFATO, 2016, p.311-312).

O excerto fornece informações sobre a viagem dos imigrantes, determinando com clareza sua origem vêneta por meio das referências ao rio Brenta, às montanhas Dolomitas, à Basílica de Santo Antônio em Pádua. De sua aldeia na Itália (o "paesello") ao porto do Rio de Janeiro, uma viagem difícil não só devido à sujeira e ao desconforto, mas principalmente porque se trazia também "uma praga, uma maldição", que parece ser explicitada pelas imagens que se seguem: "proprietários do impossível retorno, ignorantes do daqui a pouco, no nunca jamais enterrados os ossos antepassados". Neste trecho se escancara a visão que Luiz Ruffato tem da imigração italiana em Minas Gerais e sobre a qual escreveu na edição digital de El País:

A imigração é sempre a encenação de uma tragédia. Ao deixar o torrão natal - e essa é uma decisão tomada quando já não resta nenhuma esperança -, somos obrigados a abandonar não apenas a língua materna, os costumes, as paisagens, mas, mais que tudo, os ossos dos entes queridos, ou seja, o signo que indica que pertencemos a um lugar, a uma família, que possuímos, enfim, um passado (RUFFATO, 2016a).

O processo histórico da imigração é, portanto, um percurso cujo desdobramento está inevitavelmente destinado a um desfecho punitivo e catártico. O desequilíbrio, a húbris que se deve purgar, parece ser a decisão de "deixar o torrão natal" - e ainda que aqueles que tomem tal decisão não tenham alternativa - têm de inexoravelmente enfrentar as consequências de sua atitude quando o destino com suas peripécias expuser a falta cometida. O romance reencena o que, de acordo com o autor, por si já é uma tragédia, ou seja, um texto dramático no qual o destino dos personagens está traçado de antemão pelos desígnios do destino. Qual o sentido de encenar por meio da ficção algo que já é por si mesmo um enredo cujo desfecho previamente determinado é inexorável? Por que invocar todo um cabedal de técnicas e formas narrativas se se vai contar o que se sabe de antemão como vai terminar? Vale destacar que, em 'Sulfato de morfina", Rufatto emprega distinções tipográficas a fim de identificar as diferentes vozes representadas no texto. O uso desse recurso confere agilidade à narrativa e permite a apresentação de acontecimentos simultâneos. A exploração de recursos gráficos se vai acentuando ao longo do Inferno provisório e é parte do projeto ficcional do autor. Estabelece-se a partir disso um ponto de reflexão intransponível quando se aborda o trabalho de Luiz Ruffato: como se relacionam todo seu apuro técnico e a mundivisão de cunho 
trágico insistentemente reafirmada? Essa indagação será retomada em momento posterior deste trabalho

\section{Outras histórias-capítulos}

"Aquário" é a terceira história-capítulo de Mamma, son tanto Felice e a quarta narrativa da seção "Um céu de adobe" na edição de 2016. Apresenta uma sequência de quadros narrativos breves designados sempre pela indicação de uma localidade e de um horário. Trata-se de uma viagem empreendida por Carlos com sua mãe, Nica Finetto, de Cataguases a Guarapari, dois dias depois de terem enterrado Adalberto Silva, pai de Carlos e marido de Nica. São várias as maneiras de narrar empregadas nessa sequência de quadros, que entremeiam os diálogos entre mãe e filho a sumários em que Carlos relembra momentos do próprio passado - desde o enfrentamento com o pai até a vida que tivera em Santo André, na grande São Paulo, onde chegara a ter um casamento (já desfeito) e um filho. As diferentes focalizações são marcadas pelo emprego de tipos gráficos distintos, parênteses e outros recursos dessa natureza. Carlos já tem ascendência que mistura italianos e não-italianos e seu desenraizamento inclui o dos italianos que chegaram ao Brasil, o dos seus descendentes que saíram do mundo rural para o mundo urbano e o dos cataguasenses que se estabeleceram na conurbação paulistana. É num dos quadros dessa narrativa que se apresenta a cena que se pode considerar um epitáfio da presença italiana na Zona da Mata mineira:

- Sabe que lembro direitinho da vovó, mãe?

- Lembra?

- Como se fosse hoje.

- Mas você era tão pequeno quando ela morreu...

- Nem tanto, mãe... eu tinha uns oito, nove anos... Quando ela acordava, passava um tempão penteando os cabelos pra fazer um coque...
- Você lembra disso?

- E lembro também que ela só usava vestido escuro...

- Até onde vejo, desde sempre ela só usava roupa escura...

- Ela não falava nada de português, mãe?

- Nada, coitada... Nunca aprendeu... Nem uma palavra...

- A senhora sabe italiano?

- Ih, já esqueci...

- Mas a senhora sabia?

- Em criança...

- Não lembra mais nada?

- Só a reza...

- A reza a senhora lembra?

- Lembro... 0, Dio, Padre Buono e misericordioso...

- Coitada da vovó... Do quê que ela morreu?

- Solidão.

- Solidão? Ninguém morre de solidão, mãe...

- Ela morreu. Depois que venderam o resto da fazenda, ela ficou pulando de casa em casa. Até com a gente passou um ano... Mas não conseguia conversar com as pessoas. Ninguém mais sabia italiano. Os filhos não tinham paciência de puxar pela memória... Os netos remedavam ela... Ficava tempos sem abrir a boca... Até que começou a secar, secar... Um dia acharam ela murchinha, de bruços, na cama... (RUFFATO, 2016, p. 260-261).

O recurso ao discurso direto e à marcação por local e horário como subtítulo de cada quadro indicam a apropriação de técnicas narrativas do teatro ou do audiovisual. É como se se oferecesse ao leitor um momento narrativo sobre o palco ou numa tela. Persiste percucientemente a visão da imigração como tragédia: a solidão da avó que definha pouco a pouco por não ter com quem conversar em italiano é um signo poderoso da concepção de perda de raízes em que Ruffato sustenta sua interpretação. Alienada de seu espaço vital, distante da fazenda e do mundo italiano, a avó literalmente "seca". A inapetência do próprio Carlos em relação à vida parecer ser um prolongamento dessa aridez existencial e reproduz em Santo André a 
tragédia da avó em Cataguases: sem identidade na cidade industrial, não consegue obter satisfação no trabalho, no casamento, na paternidade e, a seu modo, definha, murcha ainda em vida.

Em "A expiação", há uma cena que ilustra com crueza como na origem da maldição dos imigrantes parece estar também a reprodução do processo de ocupação violenta que os primeiros colonizadores levaram a cabo a partir do século XVI. Orlando Spinelli, tio do personagem Carlos de "Aquário", havia adotado um menino negro que aparecera em sua propriedade e logo ganhou o apelido familiar de Badeco. Aos domingos, Orlando Spinelli deixava a família em casa e, em companhia do rapaz em que se transformara o menino, costumava cometer desatinos no pequeno centro urbano de Rodeiro. Numa dessas ocasiões, ocorreu o que segue:

"Está rindo de quê?, negro safado!" E, tomando a dianteira, postou à sua frente. "Rindo de quê?, pau-de-fumo! Não dou essas confianças procê não, uai!" Amedrontado, Badeco esgueirou para a porta da venda, mas Orlando, liso, interceptou-o, e, antes que pudesse reagir, tomou um safanão na orelha. Ainda zonzo, correu para o jardim. A italianada saiu para a rua, achando graça em tudo. Esse Orlando Spinelli! Orlando voltou, "Pivatto, quanto devo?" Tirou o dinheiro do bolso, jogou-o sobre o balcão. "Já vai?" "Vou é pegar esse macaco..." Cruzou a rua e se posicionou perto do coreto, de onde avistava o empregado. "Badeco!", ô, Badequim, vambora..." E ele, sem arredar o pé, cismado. "Vou não, meu padrim". "Vem, Badequim, não vou fazer nada não, vem...” E, ele, amolado, “Vou não, meu padrim, o senhor vai me bater..." "Ô, raio, não estou falando que não vou fazer nada?!" "O padrim promete?" "O!", e beijou os dedos em cruz em direção à igreja de São Sebastião. Badeco veio vindo devagar, desconfiado, pé adiante, pé adetrás. Orlando entrou na venda, tratou qualquer coisa com dois bobos alegres, e regressou. "Vem Badequim, vem". Badeco aproximou, olhos precavidos. Orlando agarrou-o, "Para, padrim, para", deu-lhe uma gravata, jogou-o no chão, imobilizando-o. "Padrim, o senhor está me machucando, padrim, para, pelo amor de deus, padrim". Os dois beberrões amarraram bem forte a corda-bacalhau em volta da cintura, juntando os braços ao quadril, e entregaram a ponta para o Orlando. Badeco já não gritava, apenas chorava, humilhado. Orlando mandou que ele fosse para a calçada, subiu na charrete, falou: "Agora, demônio de uma figa, você vai dar uma volta no jardim, bem bonitinho, igual a um tiziu!" Badeco resistiu mas o Orlando pegou o relho e acertou-lhe duas chibatadas nas costas. “Ai, padrim! Ai, padrim!" E começou a desfilar. Orlando cortava a couro o ar. E agrupou um povo: uns, os mais velhos, protestavam que aquilo era um absurdo, Aonde já se viu uma coisa dessas?!; outros, os mais novos, lançavam gritos de incentivo, Vai Badeco, ôôôa! Na terceira volta, Uh!, Badequim, uh!, Badequim, surgiu um soldado: "Para com isso já!" Orlando mirou-o e falou, dirigindo-se à aglomeração: "Ué, um macaco veio salvar o outro?" E a horda caiu na gargalhada." (RUFFATO, 2016, p. 207-208).

Sob o álibi da embriaguez, Orlando Spinelli literalmente teatraliza com ódio e truculência o aviltamento do negro na escravidão do Brasil colonial e imperial. Afloram nesse momento etílico preconceitos que não eram individuais, já que o narrador generaliza o comportamento com o uso do coletivo "a italianada", marcado pela oralidade e índice da naturalização da atitude discriminatória. Num segundo momento, a narrativa vai indicar que há divisões no grupo, pois apenas os mais jovens aplaudem a sequência dos acontecimentos, ao passo que os mais velhos passam a recriminar o comportamento de Orlando. A cena termina numa espécie de vil apoteose da explicitação do preconceito de cor e de classe quando ocorre a intervenção do soldado. Confronte-se o excerto ficcional com a narrativa histórica sobre a imigração europeia no mundo rural brasileiro:

Uma relação de vizinhança difícil se estabeleceu também com os negros e caboclos, provavelmente a mais difícil. Precisavam e se serviam dos conhecimentos destes, sobretudo nos primeiros tempos, para se adaptar ao novo país, mas, contraditoriamente, não hesitavam em menosprezá-los. Mesmo sofrendo toda espécie de preconceito por parte da elite brasileira, que via os imigrantes como sujos, mendigos que vieram procurar comida no Brasil, eles não tinham para com os brasileiros menos aquinhoados uma relação de igualdade; pelo contrário, sempre se julgaram superiores (ALVIM, 2001, p. 272). 
Neste caso, o ficcional e o histórico se solidarizam e embasam o que se vinha afirmando neste percurso analítico: a queda dos imigrantes italianos e sua expulsão simbólica do paraíso americano se deu também porque reencenaram procedimentos opressivos e desumanos da primeira colonização europeia. À maldição de origem - o terem abandonado o lugar de nascimento - soma-se esta outra.

Na última das histórias-capítulos de Mamma, son tanto felice, "O segredo", integrada à seção "Vista parcial da noite” na edição de 2016, há 25 segmentos de extensão variada que contam parte substancial da vida de um descendente de italianos, o professor Francisco Pretti, alguém que, devido às circunstâncias que viveu, teria em tese condições de ascender socialmente e desfrutar de uma vida equilibrada. Isso não se dá, no entanto, pois o personagem, ainda que usufrua de conforto material, é desestabilizado afetivamente por sentimentos cuja origem não se evidencia com clareza. Leia-se a seguinte sequência, em que, levado por motivos não definidos, ele toma o ônibus e revisita o lugar de onde provinha:

Lá longe, uma casinha de sapé, fechada, abandonada, Ninguém mais quer ficar na roça, a moda agora é a cidade; outra, suspensa no despenhadeiro, paredes arriadas, destelhada, a cruz envolvida numa massa disforme, um dia papel-crepom colorido ainda agarrada à porta agora desnecessária... Andar, andar, andar, perder-se nas entranhas das serras, nos grotões, deixar ao acaso a escolha de uma vereda que o empurre cada vez para mais distante... À beira do caminho, as choças iam ficando para trás, ali morava o Orlando Spinelli; lá, a fazenda dos Bettio; acolá, os Finetto; na virada do morro, os pastos Benevenutti... Alá! Os meninos roçando o pasto, colhendo milho, cavucando buraco atrás de tatu, de lagarto... Alá! Os meninos cascando laranjas, correndo atrás de charrete, candeando junta de boi, sempre camisas xadrezes cerzidas, pés escalavrados, chapéus enfiados na cabeça ô, ô, ô, ô, cumprimenta o passante, Tarde!, Tarde!, E a comadre?, Vai benzinho, como a Deus é servido! Quer entrar não?, tomar um cafezinho? Lonjuras, tudo vazio, cresce a capoeira, o matagal engole as glebas, sufoca as árvores, o carro-de-boi sem roda apodrece debaixo de uma cumeeira do que um dia foirancho de curar fumo, vozes, o vento aboia um lamento, e a palma dos pés como que lê antigas pegadas, vence a noite assoberbada, o breu pespega os olhos, o pio da coruja, Bicho ordinário Tem uma tronqueira ali, desincumbe-se do arame farpado, a casa deve de estar, escorrega para dentro de uma voçoroca, apruma, engolfa de novo, o corpo desequilibra, rola valeta abaixo, lanho no braço, arranhão na perna, $O$ que estou fazendo aqui, meu deus?, rasgo no paletó, some um pé do sapato, senta num tufo, desconsolado, vontade enorme de, $O$ quê que eu vim fazer aqui, meu deus? Fecha os olhos. Abre os olhos. A casa! A sua casa! (RUFFATO, 2016, p.122-123).

O que se narra é eloquentemente claro: Francisco Rossi já não sabe nem sequer como caminhar no mundo em que nasceu e cresceu, tamanha a distância que o separa de suas origens. Está aí apresentado em sua dissolução o que um dia foi o conjunto das realizações dos imigrantes italianos na Zona da Mata mineira: das propriedades das famílias Spinelli, Bettio, Finetto, Benevenutti e Pretti restam escombros. E algumas páginas adiante o professor formula com lucidez a causa de seu deslocamento existencial permanente: "Perdi minhas antigas referências, a roça, meu sangue, a paisagem da infância... E não acrescentei nada a isso... $O$ que resta do passado? Ruínas... Apenas ruínas..." (RUFFATO, 2016, p. 135).

Aqui convém encaminhar este percurso a alguma conclusão. "Ruínas" são o que resta do passado, não apenas no caso particular do professor Francisco Pretti, mas dos imigrantes italianos e seus descendentes da Zona da Mata mineira representados por Luiz Ruffato a partir de Mamma, son tanto Felice e ao longo de todo o Inferno provisório. É uma concepção que o autor explicitamente expõe no artigo do El País aqui citado - e que pode ser reencontrada em entrevistas e depoimentos disponíveis em periódicos ou em sítios da internet. 0 recurso a formas de narrar que incorporam soluções formais experimentais e permitem esquemas de focalização que fogem aos modelos narrativos mais convencionais aponta para uma questão que interessa profundamente às formulações da teoria da narrativa: não é o 
aparato técnico do escritor que condiciona possibilidades de interpretação aberta ou formula possibilidades muito intensas de participação do leitor no desvendamento da obra, pois, no que diz respeito à leitura do processo imigratório italiano em Minas Gerais, prevalece por sobre toda a inovação formal de superfície - por si mesma válida como conformação final do texto literário - a formulação do juízo de Ruffato: encenou-se uma tragédia, percorreu-se um caminho cujo desfecho se fazia prever desde o princípio, em que erros capitais instauraram a inevitabilidade da extinção a que se estava destinado. Extinção aqui não significa, como no caso do personagem Carlos, há pouco analisado, morte ou supressão física, mas sim desumanização do humano, existência esvaziada de sentido pela ausência de referenciais identitários. Assim Ruffato associa a sofisticação formal a um profundo senso de esvaziamento existencial, assim a modernidade se desdobra como passos de uma tragédia em direção ao momento punitivo. Atente-se para o fato de que não se trata de uma causalidade de natureza determinística: muitos personagens de Inferno provisório se libertam de suas limitações de classe e ascendem socialmente, ou seja, não há condicionamentos de matiz mesológico nem hereditário. 0 grande constrangimento decorre do fato de que a sociedade humana se organiza em esquemas predatórios, seja na origem ironicamente edênica dos tempos, seja na sociedade de consumo do século XXI. Daí esse desenraizamento por assim dizer atávico que é norma existencial em Inferno provisório: o mundo não provê condições existenciais dignas a quem não adere convictamente às práticas sociais baseadas na posse e na instrumentalização dos outros.

\section{Referências}

ALVIM, Zuleika. Imigrantes: a vida privada dos pobres do campo. In: SEVCENCO, Nicolau (Org.). História da vida privada no Brasil - República: da Belle Époque à Era do Rádio. São Paulo: Companhia das Letras, 2001. p. 215-287.
BÍBLIA DE JERUSALÉM. São Paulo: Paulus, 2002.

FREUD, Sigmund. Obras completas. Volume 11: Totem e tabu, contribuição à história do movimento psicanalítico e outros textos (1912-1914). São Paulo: Companhia das Letras, 2013.

PESSOA, Fernando. Mensagem - Poemas esotéricos. (Edição crítica de José Augusto Seabra). Madri-Paris: ALLCA XX, 1993.

RUFFATO, Luiz. Mamma, son tanto felice. Rio de Janeiro: Record, 2005.

RUFFATO, Luiz. Luiz Ruffato e o sonho do paraíso na metrópole. O Estado de S. Paulo, São Paulo, 08 out. 2008. Disponível em: <https://cultura.estadao.com.br/noticias/geral,luizruffato-e-o-sonho-do-paraiso-na-metropole,255636>. Acesso em: 17 jun. 2018.

RUFFATO, Luiz. Domingos sem Deus. Rio de Janeiro: Record, 2011.

RUFFATO, Luiz. Luiz Rufatto mescla realidade e ficção em seu novo livro. O Estado de S. Paulo, São Paulo, 14 jun. 2014. Disponível em: <https://cultura.estadao.com.br/ noticias/literatura,luiz-ruffato-mescla-realidade-e-ficcao-em-seu-novo-livro,1511553>. Acesso em 17 jun. 2018.

RUFFATO, Luiz. Inferno provisório. São Paulo: Companhia das Letras, 2016a.

RUFFATO, Luiz. Os italianos invisíveis de Minas Gerais. El País, Brasil, 13 jan. 2016b. Disponível em: <https://brasil.elpais.com/brasil/2016/01/13/opinion/1452701029_ 579409.html>. Acesso em: 17 jun. 2018.

Recebido em 17/06/2018 Aceito em 27/09/2018. 